\title{
Novel Amphibole Geo-barometer with Application to Mafic Xenoliths
}

\author{
Alexander Simakin ${ }^{1,2}$, Olga Zakrevskaya ${ }^{2} \&$ Tamara Salova $^{2}$ \\ ${ }^{1}$ Institute of Physics of the Earth, RAS, Moscow, Russia \\ ${ }^{2}$ Institute of Experimental Mineralogy, RAS, Chernogolovka, Russia \\ Correspondence: Alexander Simakin, Institute of Experimental Mineralogy, Russian Academy of Science, \\ Chernogolovka, Moscow region, 142432, Russia. Tel: 7-496-522-5853. E-mail: simakin@ifz.ru
}

Received: March 23, 2012 Accepted: April 10, 2012 Online Published: June 5, 2012

doi:10.5539/esr.v1n2p82 URL: http://dx.doi.org/10.5539/esr.v1n2p82

\begin{abstract}
Amphibole crystallization from hydrous high-magnesium andesite (Shiveluch volcano, Kamchatka) melt has been studied experimentally at pressures 2,3,5 kbar. Slightly subliquidus temperatures have been selected for amphibole crystallization. Amphiboles with close to the equilibrium composition have been obtained at low undercoolings in short 4 hours experiments. We select octahedral aluminium content and sum of high charged cations $\left(\mathrm{Ti}^{4+}, \mathrm{Fe}^{3+}\right)$ all evaluated with the $13 \mathrm{eCNK}$ method as master parameters reflecting pressure of amphibole formation. Asymptotic maximum of $\mathrm{Al}^{\mathrm{VI}}$ content at the sum $\mathrm{Ti}+\mathrm{Fe}^{3+}=0$ as a function of pressure was calculated following negative linear correlation trend for each run of the original and published experimental data sets. The derived novel $\mathrm{Al}^{\mathrm{VI}}$ in amphibole barometer is calibrated in the pressure range of 2-12 kbar for andesitic and basaltic magmas. Reliability and validity of the new geobarometer were tested on the amphibolized ultramafic xenoliths from the Shiveluch Volcano (Kamchatka) and Dish Hill (California). In both cases our estimates appear to be equal within the uncertainty of the method to the predictions done by two-pyroxene geo-thermo-barometer (Putirka, 2008).
\end{abstract}

Keywords: amphibole, geobarometer, andesite

\section{Introducation}

The estimates of PT parameters and oxygen fugacity in the magmatic systems are necessary for the reconstruction of petrologic mechanisms of their formation. Pressure is the most important parameter for active magma chambers since it corresponds to their depth. Reliable assessment of the magma chamber depth is important for interpretation of geophysic and geodetic data in the areas of active volcanism and for the eruption prediction (e.g., Manley \& Bacon, 2000). Oxygen fugacity and fluid composition are essential for ore generation potential of magmas (Moretti \& Baker, 2008). In petrologic practice various mineralogical geo-thermo-barometers are used to determine PT parameters of water bearing magmas. Two-pyroxene (Putirka, 2008) and spinels composition based QUILF (Andersen et al., 1993) thermo-barometers are known as the most reliable ones.

Amphibole is a mineral typical for calk-alkaline magmas stable at water content above ca $2 \mathrm{wt} . \%$ in the pressure range 1.5-12 kbar or from the crustal to near Moho (crust-mantle boundary) depths. This phase composition reflects PT and $\mathrm{f}_{\mathrm{O} 2}$ of the parental melt and is used to calibrate solo amphibole (Schmidt, 1992; Anderson \& Smith 1995) and amphibole-plagioclase (Blundy \& Holland, 1990) geo thermo-barometers. Recently Ridolfi et al. (2010) have proposed empirical universal amphibole sensor to estimate of $\mathrm{f}_{\mathrm{O} 2}$ and PT parameters. However, most of the experimental data used for calibration of the above mentioned models relate to the low temperature amphiboles grown from dacitic and rhyolitic melts. The accumulation of the precise information on the equilibrium amphibole compositions in andesitic and basaltic systems is timely goal for the experimental study. Low viscosity of the hydrous basic melts complicates experimentation by easy secondary nucleation and low temperature overgrowth at quenching. Other factors, that can distort equilibrium composition are undercooling at growth and melt fractionation. At a large degree of crystallization nominally (initially) andesitic and basaltic melts get silicic composition. Therefore, a great fraction of the published analyses of the allegedly equilibrium amphiboles can't be used in the empirical calibrations. Furthermore, totally empirical calibrations (like in Ridolfi et al., 2010) lack a physico-chemical analysis of the isomorphism and cation exchange between amphibole and melt. 
In our early study (Simakin et al., 2009) we find that at the fixed pressure inverse correlation exists between the sum of high valence cations $\left(\mathrm{Fe}^{3+}+\mathrm{Ti}^{4+}\right)$ and the content of aluminum in octahedral coordination state in amphibole. In the highly oxidized melt $\mathrm{Al}^{\mathrm{VI}}$ in amphibole is totally substituted with ferric iron, whereas in the highly reduced melt octahedral aluminium attains the maximum content. In this study we employ this correlation to derive novel $\mathrm{Al}^{\mathrm{VI}}$ in amphibole geo-barometer while using new data of the experiments with hydrous andesitic melt at pressures 2, 3,5 kbar. A new geo-barometer was applied to estimate equilibration pressure of mafic xenoliths from the Shiveluch volcano (Kamchatka) and Dish Hill (California).

\section{Method}

\subsection{Starting Materials and Equipment}

A high magnesium andesite of the Shiveluch volcano (Kamchatka) was used as a starting material (composition in the Table 1). This andesite was from the Holocene extrusion Karan representing rock with high degree of crystallinity and uniform texture containing amphibole and plagioclase phenocrysts. Hydrous glass was prepared for the further use from the rock powder in IHPV device. Rock powder was placed in platinum capsules with water, welded and held at the pressure of the future experiments $\left(2,3,5 \mathrm{kbar}\right.$, respectively) and $\mathrm{T}=1300^{\circ} \mathrm{C}$.

Table 1. Compositions of the starting glasses recalculated to the sum $100 \%$. All glasses are water saturated and prepared at the same temperature $\mathrm{T}=1300^{\circ} \mathrm{C}$.

\begin{tabular}{llllllllllll}
\hline run & $\mathrm{P}, \mathrm{kbar}$ & $\mathrm{Na}_{2} \mathrm{O}$ & $\mathrm{MgO}$ & $\mathrm{Al}_{2} \mathrm{O}_{3}$ & $\mathrm{SiO}_{2}$ & $\mathrm{~K}_{2} \mathrm{O}$ & $\mathrm{CaO}$ & $\mathrm{TiO}_{2}$ & $\mathrm{Cr}_{2} \mathrm{O}_{3}$ & $\mathrm{MnO}$ & $\mathrm{FeO}$ \\
\hline $\mathrm{An} 65$ & 2 & 4.16 & 5.24 & 15.87 & 59.87 & 1.29 & 6.84 & 0.69 & 0.05 & 0.10 & 5.91 \\
$\mathrm{An68}$ & 3 & 4.24 & 5.45 & 16.34 & 59.70 & 1.30 & 7.11 & 0.71 & 0.05 & 0.14 & 4.96 \\
$\mathrm{An} 69 *$ & 5 & 3.19 & 4.34 & 16.67 & 60.48 & 0.92 & 7.86 & 0.77 & 0.00 & 0.20 & 5.49 \\
\hline
\end{tabular}

* significant deviation of this composition reflects glass heterogeneity due to fast rates of diffusion and crystals growth and segregation at the quenching of the hydrous andesitic melt at $\mathrm{P}=5 \mathrm{kbar}$ with low viscosity

Table 2. Conditions of experiments and their products

\begin{tabular}{|c|c|c|c|c|c|c|}
\hline$\#$ & run & $\mathrm{T}\left({ }^{\circ} \mathrm{C}\right)$ & $\mathrm{P}$ (kbar) & Time $(\mathrm{h})$ & Overheating & Phases \\
\hline 1 & An 65 & 1300 & 2 & 8 & na & gl (amph) \\
\hline 2 & An 65-1 & 950 & 2 & 4 & No & $\mathrm{gl} \mathrm{cpx}, \mathrm{pl}, \mathrm{amph}(\mathrm{ol})$ \\
\hline 3 & An 68 & 1300 & 3 & 8 & na & $\mathrm{gl}(\mathrm{cpx}, \mathrm{amph})$ \\
\hline 4 & An $68-1$ & 930 & 3 & 4 & No & $\mathrm{gl} \mathrm{amph,} \mathrm{pl}$ \\
\hline 5 & An $68-3$ & 930 & 3 & 4 & Yes & $\mathrm{gl}, \mathrm{cpx}, \mathrm{amph}, \mathrm{spl}$ \\
\hline 6 & An $68-2$ & 965 & 3 & 4 & No & $\mathrm{gl}, \mathrm{cpx}, \mathrm{amph}, \mathrm{spl}$ \\
\hline 7 & An $68-5$ & 965 & 3 & 4 & Yes & $\mathrm{gl}(\mathrm{cpx}, \mathrm{amph}, \mathrm{spl}, \mathrm{pl})^{*}$ \\
\hline 8 & An 68-6 & 980 & 3 & 4 & Yes & $\mathrm{gl}(\mathrm{cpx}, \mathrm{amph}, \mathrm{spl}, \mathrm{pl})^{*}$ \\
\hline 9 & An 69 & 1300 & 5 & 8 & na & $\mathrm{gl}(\mathrm{cpx}, \mathrm{amph})$ \\
\hline 10 & An 69-3 & 970 & 5 & 4 & Yes & gl, cpx, amph, spl (pl) \\
\hline 11 & An 69-4 & 980 & 5 & 4 & Yes & $\mathrm{gl}(\mathrm{amph}, \mathrm{spl})^{*}$ \\
\hline 12 & An 69-1 & 990 & 5 & 4 & No & $\mathrm{gl}, \mathrm{amph},(\mathrm{cpx}, \mathrm{pl})$ \\
\hline 13 & An 69-2 & 1030 & 5 & 4 & No & gl (amph)* \\
\hline
\end{tabular}

Phases abbreviations: gl - glass, amph - amphibole, cpx - clinopyroxene, spl - spinel, pl - plagioclase, quenching phases are in parenthesis, * tentatively interpreted as quenching phase based on its composition and morphology.

Oxygen fugacity at the glass preparation is controlled by high pressure vessel material on the level around NNO +0.5 . Even a small amount of air remaining in a capsule increases oxygen fugacity at the beginning of the run (Simakin \& Salova, 2004). Therefore, at every stage before welding a capsule was flashed with high purity argon to remove air. This operation is especially effective at the arrangement of charges with compact pieces of 
hydrous glass (not powder) for the final runs. The run lasted 4-6 hours. Iron loss into the capsule walls for this short time has an acceptable level (see Table 1) and as shown in our earlier studies iron oxidation state remains close to the initial one (Simakin et al., 2009). The summary of the run P-T-t conditions and a list of the produced phases for each run are in Table 2. The effect of the melt superheating prior main stage of the experiment on the amphibole growth and composition will be considered below using the obtained experimental data.

\subsection{Method of Crystallochemical Calculations}

We recalculate amphibole analyses at the treatment of the experimental data on the basis of the method recommended by IMA (classification IMA-97, Leake et al., 1997) for calcium amphiboles. As well established amphibole has general chrystallo-chemical formula $\mathrm{A}_{0-1} \mathrm{M} 4{ }_{2} \mathrm{M} 2_{2} \mathrm{M} 3_{1} \mathrm{Ml}_{2}\left(\mathrm{~T}_{8} \mathrm{O}_{22}\right) \mathrm{X}_{2}$, where position $\mathrm{A}$ is occupied with large cations $\mathrm{Na}$ and $\mathrm{K}, \mathrm{T}$ with tetrahedral $\mathrm{Al}$ and $\mathrm{Si}, \mathrm{X}$ - anion position mainly filled with $\mathrm{OH}$ - and partially $\mathrm{Cl}^{-}, \mathrm{F}^{-}, \mathrm{O}^{2-}$. Octahedral positions $\mathrm{M} 1,2,3$ are for divalent and high charge cations (mainly $\mathrm{Mg}^{2+}, \mathrm{Fe}^{2+}$, $\left.\mathrm{Al}^{3+}, \mathrm{Fe}^{3+}, \mathrm{Ti}^{4+}\right)$. Distorted M4 position is mainly for $\mathrm{Na}$ and $\mathrm{Ca}$. There is a cation ordering with preferable occupancy of pair (per formula unit) of M2 sites with high valence cations: $\mathrm{Fe}^{3+}, \mathrm{Al}^{3+}, \mathrm{Ti}^{4+}$ (Deer et al, 1997). IMA-97 method is known as $13 \mathrm{eCNK}$ (13 cations excluding $\mathrm{Ca}, \mathrm{Na}, \mathrm{K}$ ) and implies that M1-3 and $\mathrm{T}$ sites are fully filled with tetrahedral and small cations while alkalies and calcium fill the rest of M4+A sites. The accuracy of these calculations can be reduced when some portion of small cations (Adam et al., 2007) would shift to M4 site.

Cation distribution and iron oxidation state calculated from microprobe analyses reflect amphibole state at the moment of crystallization from the parental melt with uncertainty related to analytical precision and model assumptions validity. Later on mineral dehydration and partial iron oxidation can occur in accordance with reaction (Popp et al., 1995):

$$
\mathrm{Fe}^{2+}(\mathrm{OH})^{-}+1 / 4 \mathrm{O}_{2} \rightarrow \mathrm{Fe}^{3+} \mathrm{O}^{2-}+1 / 2 \mathrm{H}_{2} \mathrm{O}
$$

This process disvalues the results of the direct (e.g. Mossbauer) determination of $\mathrm{Fe}^{3+} / \mathrm{Fe}^{2+}$ ratio in amphibole and gives preference to crystallo-chemical calculations to reconstruct the as-grown amphibole state related to the parental magma properties. Large systematic work on the comparison of the results of the direct determination and calculation with different methods of the iron oxidation state in calcic amphiboles of the diverse origin was performed by Gualda and Vlach (2005). These authors found that the lowest measured ferric/ferrous ratios appeared to be close to the calculated ones while most of measurements were significantly higher than the results of the crystallochemical calculations by $13 \mathrm{eCNK}$ method as expected due to the post growth oxidation.

\subsection{Composition Representation}

The recalculated amphibole compositions were plotted in the coordinates $\left[\mathrm{Fe}^{3+}+\mathrm{Ti}, \mathrm{Al}^{\mathrm{VI}}\right]$. The selected analyses are presented in Table 3. These parameters reflect pressure and oxygen fugacity at the growth stage (Simakin et al., 2009). Octahedral aluminum content and the sum of high valence cations $\mathrm{Fe}^{3+}+\mathrm{Ti}$ are linearly correlated. Intersection with ordinate gets maximum octahedral aluminum content $\mathrm{Al}^{\mathrm{VI}}{ }_{\text {max }}$ at given pressure while intersection with abscissa defines the maximum content of high valence cations (except aluminum) that is about 1.8 apfu for calcic magmatic amphiboles grown from the melt. Parameter $\mathrm{Al}^{\mathrm{VI}}$ max reflects pressure better than merely $\mathrm{Al}^{\mathrm{VI}}$ content depending on the iron oxidation degree or oxygen fugacity at mineral growth.

Table 3. Chemical composition of experimental amphiboles

\begin{tabular}{lccccccccccc}
\hline run P/T & $\mathrm{Na}_{2} \mathrm{O}$ & $\mathrm{MgO}$ & $\mathrm{Al}_{2} \mathrm{O}_{3}$ & $\mathrm{SiO}_{2}$ & $\mathrm{~K}_{2} \mathrm{O}$ & $\mathrm{CaO}$ & $\mathrm{TiO}_{2}$ & $\mathrm{Cr}_{2} \mathrm{O}_{3}$ & $\mathrm{MnO}$ & $\mathrm{FeO}$ & $\mathrm{Total}$ \\
\hline An68-2 3/965* & 2.17 & 16.81 & 12.03 & 45.21 & 0.36 & 11.43 & 1.19 & 0.16 & 0.00 & 7.94 & 97.65 \\
& 2.23 & 15.36 & 11.63 & 42.19 & 0.32 & 11.51 & 1.02 & 0.12 & 0.31 & 8.85 & 93.77 \\
& 2.11 & 15.14 & 12.28 & 41.42 & 0.31 & 11.58 & 0.82 & 0.00 & 0.23 & 9.18 & 93.47 \\
& 2.20 & 15.20 & 12.35 & 42.46 & 0.40 & 11.64 & 0.88 & 0.05 & 0.27 & 9.16 & 94.92 \\
\hline An68-6 3/980 & 1.99 & 16.31 & 11.43 & 42.98 & 0.44 & 11.25 & 1.69 & 0 & 0.36 & 8.61 & 95.06 \\
& 2.03 & 15.98 & 11.66 & 42.68 & 0.32 & 10.37 & 1.25 & 0 & 0 & 8.38 & 92.67 \\
& 1.88 & 15.67 & 11.25 & 41.95 & 0.36 & 11.23 & 1.57 & 0 & 0 & 8.47 & 92.37 \\
& 2.2 & 14.95 & 11.4 & 41.36 & 0.45 & 10.34 & 1.12 & 0 & 0 & 8.33 & 90.14 \\
& 2.42 & 16.16 & 11.26 & 44.69 & 0.45 & 10.81 & 1.21 & 0 & 0.38 & 8.04 & 95.41 \\
& 2.01 & 16.36 & 11.25 & 43.15 & 0.39 & 11.19 & 1.46 & 0 & 0 & 8.29 & 94.1 \\
& 2.16 & 16.53 & 11.4 & 42.63 & 0.49 & 10.18 & 1.15 & 0 & 0 & 7.96 & 92.51 \\
\hline
\end{tabular}




\begin{tabular}{cccccccccccc}
\hline An69-1 5/990 & 2.14 & 14.71 & 11.74 & 44.07 & 0.34 & 11.69 & 0.84 & 0.14 & 0.19 & 9.3 & 95.36 \\
& 2.24 & 14.45 & 12.48 & 42.83 & 0.36 & 11.42 & 0.92 & 0.1 & 0.03 & 8.09 & 92.98 \\
& 2.15 & 14.54 & 12.07 & 42.68 & 0.44 & 11.41 & 1.23 & 0.21 & 0.33 & 8.98 & 94.11 \\
& 1.98 & 13.26 & 11.38 & 40.23 & 0.4 & 10.72 & 1.2 & 0.14 & 0.19 & 9.1 & 88.66 \\
& 2 & 14.34 & 11.68 & 42.17 & 0.39 & 11.25 & 1.09 & 0.06 & 0.27 & 8.54 & 91.84 \\
& 2.08 & 14.64 & 11.41 & 42.63 & 0.44 & 10.81 & 1.23 & 0.2 & 0.24 & 7.55 & 91.26 \\
\hline An69-3 5/970 & 2.47 & 17.34 & 12.91 & 46.04 & 0.37 & 11.67 & 1.72 & 0.00 & 0.00 & 6.02 & 98.54 \\
& 2.23 & 18.49 & 11.77 & 47.62 & 0.37 & 11.73 & 1.29 & 0.00 & 0.00 & 6.20 & 99.69 \\
& 2.45 & 17.76 & 12.74 & 47.17 & 0.63 & 11.75 & 1.47 & 0.00 & 0.00 & 7.11 & 101.09 \\
& 2.28 & 17.89 & 11.93 & 47.30 & 0.42 & 11.42 & 1.22 & 0.00 & 0.33 & 7.71 & 100.49 \\
& 2.13 & 18.18 & 11.75 & 47.51 & 0.44 & 11.54 & 1.30 & 0.00 & 0.00 & 7.38 & 100.23 \\
& 2.32 & 17.35 & 11.04 & 46.33 & 0.36 & 11.09 & 1.21 & 0.00 & 0.00 & 7.64 & 97.33 \\
& 2.35 & 17.93 & 12.67 & 46.16 & 0.44 & 11.20 & 1.12 & 0.00 & 0.00 & 7.05 & 98.91 \\
& 2.34 & 17.65 & 11.56 & 45.70 & 0.41 & 11.47 & 0.83 & 0.00 & 0.00 & 6.61 & 96.57 \\
\hline An65-1 2/950 & 2.22 & 15.21 & 11.11 & 45.10 & 0.34 & 11.38 & 1.38 & 0.35 & 0.33 & 9.61 & 97.03 \\
& 2.09 & 17.65 & 11.26 & 46.53 & 0.27 & 11.37 & 1.36 & 0.00 & 0.29 & 9.18 & 100.00 \\
\hline
\end{tabular}

* pressure in kbar, temperature in ${ }^{\circ} \mathrm{C}$

\section{Results of Experiments}

\subsection{Ptotal $=\mathrm{PH}_{2} \mathrm{O}=2 \mathrm{Kbar}$}

At pressure $2 \mathrm{kbar}$ and $\mathrm{T}=950^{\circ} \mathrm{C}$ one experiment was performed to check the previously obtained results (Simakin et al., 2009). In this experiment no superheating was applied. Therefore, the sample contains a lot of quenching crystals of two kinds: formed at glass preparation and glass heating from the ambient temperature at the start of the experiment and appeared at the final quenching at the end of the run. In the Figure 1 compositions of the amphiboles obtained are displayed. They form "quenching array" approaching the extreme point with the coordinate $\left[\mathrm{Al}^{\mathrm{VI}}, \mathrm{Fe}^{3+}+\mathrm{Ti}\right]=[2 \div 2.2,0]$. The points from the previous study are shown with the error bars with their linear approximation. Only several crystals of the largest size in a smaple section are considered as potentially grown at the main stage of the experiment at the lowest undercooling and pocessing the near-equilibrium composition. The average composition of such amphiboles from the run with duration of 6 hours is plotted with the open diamond. The good correspondence between the previously obtained and new data is demonstrated.

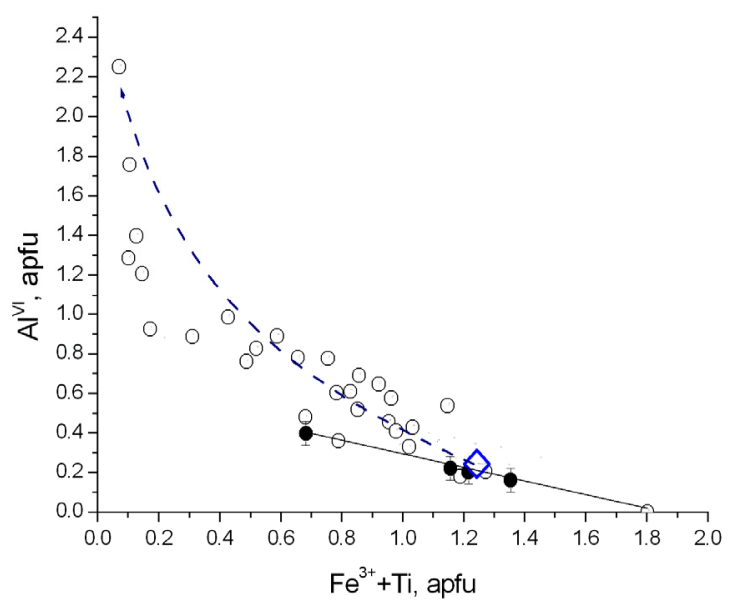

Figure 1. Compositions of amphiboles grown at $\mathrm{T}=950^{\circ} \mathrm{C}$ and $\mathrm{P}=2 \mathrm{Kbar}$; open circles stay for data obtained in the given work, filled circles with error bars connected with continuous line represent data from (Simakin et al., 2009), diamond corresponds to the averaged composition of the selected on the size and habitus basis amphibole crystals of nonquenching origin (see text) 


\subsection{Ptotal $=\mathrm{PH}_{2} \mathrm{O}=3 \mathrm{Kbar}$}

At pressure $3 \mathrm{kbar}$ the experiments have been performed at $\mathrm{T}=930,965$ and $980^{\circ} \mathrm{C}$. Superheating applied in the runs An68-5 $\left(\mathrm{T}=965^{\circ} \mathrm{C}\right)$ and An68-6 $\left(\mathrm{T}=980^{\circ} \mathrm{C}\right)$ results in the effective melting of the quenching crystalline inclusions. During the main stage of the run An68-5 no crystallization occurs since homogeneous nucleation delay time was larger than 4 hours and only quenching phases form. On the $\mathrm{Fe}^{3+}+\mathrm{Ti}-\mathrm{Al}^{\mathrm{VI}}$ plot amphibole analyses form typical quenching array as shown in Figure 1. At the same time the run An68-2 $\left(\mathrm{T}=965^{\circ} \mathrm{C}\right)$ was performed without superheating and sample observation demonstrates clots of amphibole crystals up to $20 \mathrm{mkm}$ width, representing partially recrystallized and overgrown quenching phases (see Figure 2). Analyses of these amphiboles are plotted in Figure 3. The texture of the sample An68-3 $\left(\mathrm{T}=930^{\circ} \mathrm{C}\right)$ reflects two stage growth. Superheating also removes ceneters of heterogeneous nucleation. However, undercooling higher by $35^{\circ} \mathrm{C}$ than in the run An68-5 was sufficient for homogeneous nucleation of $\mathrm{Cpx}$ and amphibole crystals. Lower temperature leads to the larger degree of crystallization and melt fractionation. Amphibole compositions from this run form "dacitic bill" toaching abscissa in Figure 3. They had growing in the melt with progressively increasing silica content (decreasing $\mathrm{Mg}$ and $\mathrm{Al}^{\mathrm{VI}}$ activity) and iron oxidation degree. Numerous tiny crystals grew at the quenching stage beyond diffusion zones.

Crystals formed in the run An68-6 $\left(\mathrm{T}=980^{\circ} \mathrm{C}\right)$ have equant morphology and relatively large sizes of quenching composition. This observation stands for the near liquidus temperature of the run An68-6 since strong superheating in the main stage of the experiment would lead to better homogenization and quenching crystallization at lower temperature with typical high supercooling morphologies. We tentatively set $T_{1}=980-990$ ${ }^{\circ} \mathrm{C}$. Then $\mathrm{T}=930^{\circ} \mathrm{C}$ corresponds to the large undercooling $\Delta \mathrm{T}=55-60^{\circ} \mathrm{C}$ able to shift $\mathrm{Al}^{\mathrm{VI}}$ content significantly from the equilibrium one. For calibration we select the largest crystals from the run An68-2 formed in the near liquidus conditions. Their analyses are plotted with open squares in Figure 3. Rather small width of crystals implying possible matrix effect at microprobe analysis and probably incomplete equilibraiton results in significant data scattering. For this reason we approximate compositional trend by the line starting at the point $\left[\mathrm{Fe}^{3+}+\mathrm{Ti}, \mathrm{Al}^{\mathrm{VI}}\right]=[1.8,0]$ and passing through the middle of the cloud of the experimental points to the intersection with ordinate. The intersection point has coordinate $\left[\mathrm{Fe}^{3+}+\mathrm{Ti}, \mathrm{Al}^{\mathrm{VI}}\right]=[0,0.67]$.

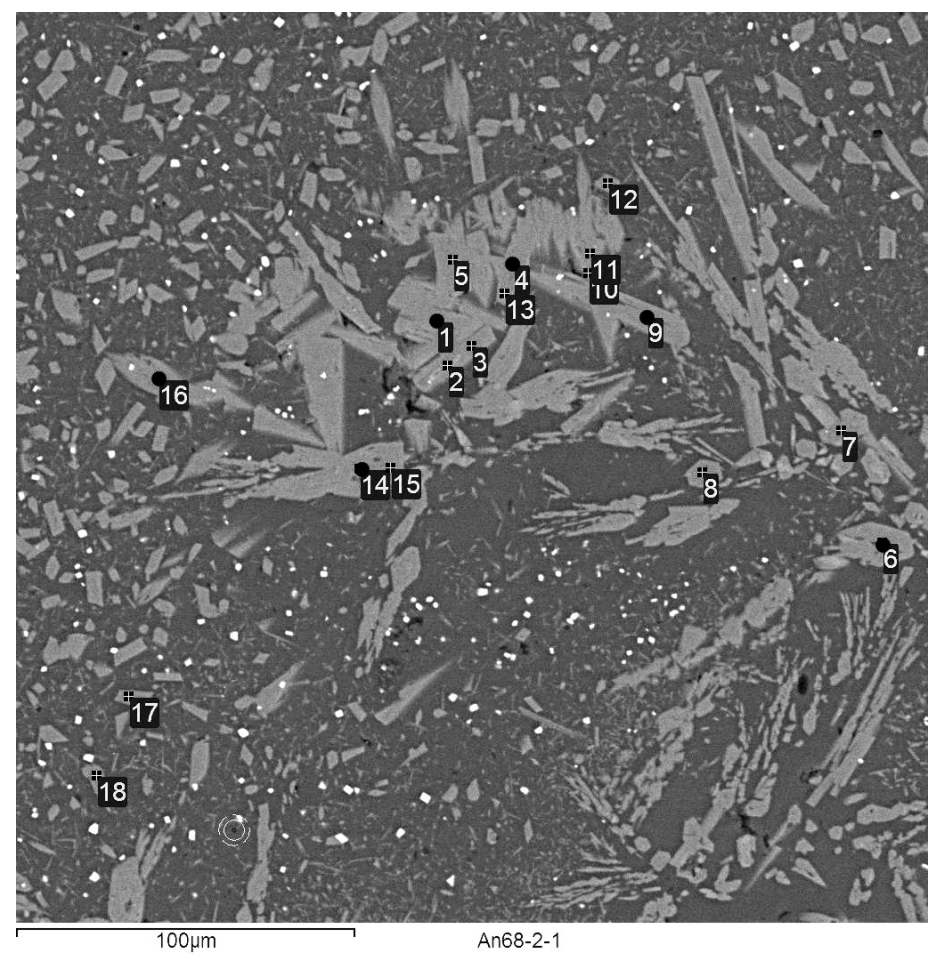

Figure 2. SEM image of the sample from the run An68-2 (see Table 2) with parameters $\mathrm{T}=965^{\circ} \mathrm{C}, \mathrm{P}=3 \mathrm{kbar}$, no overheating. Amphibole crystals labeled with solid circles are probed for calibration 


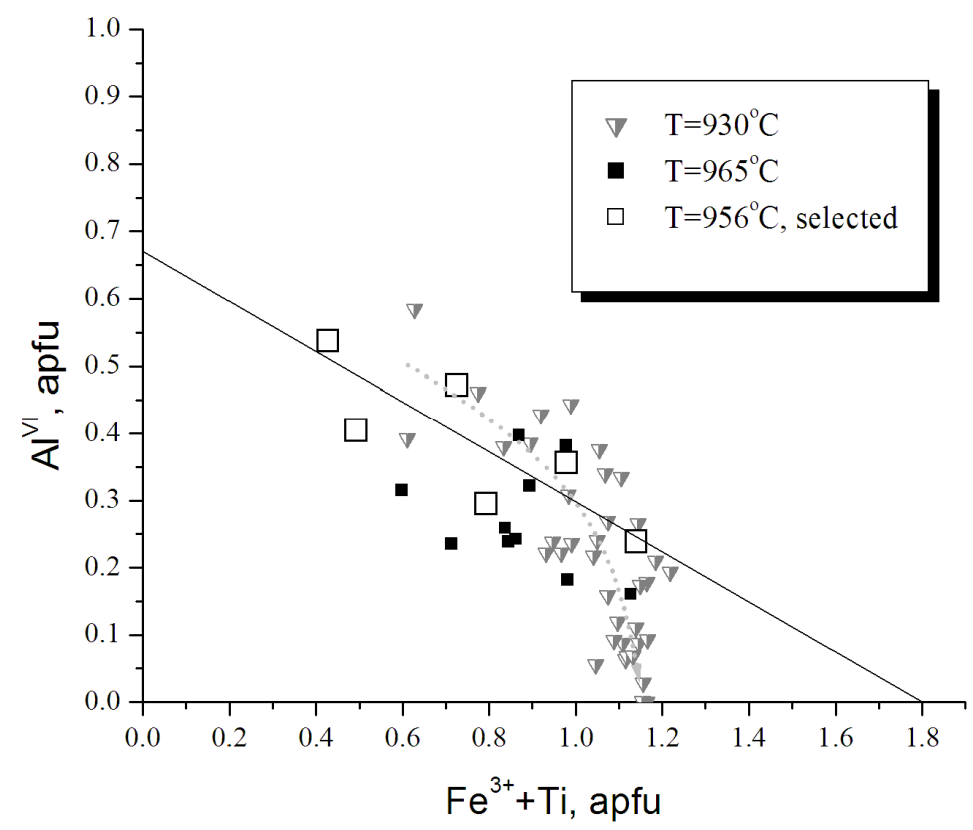

Figure 3. Parameterized compositions of amphiboles grown at pressure $\mathrm{P}=3 \mathrm{kbar}$ at the different temperatures specified in the legend. At the lower temperature $\mathrm{T}=930^{\circ} \mathrm{C}$ (run An68-3) larger degree of crystallization and fractionation are attained resulted in the "dacitic bill" trend shown with dotted line. At $\mathrm{T}=965^{\circ} \mathrm{C}$ (run An68-2) crystals are recrystallized inherited from the starting glass and partially new ones grown near liquidus, open squares stand for the selected analysis of the largest amphiboles used for calibration. Continuous line depicts linear trend passing through point $[1.8,0]$ and analyses of the selected crystals (open squares)

\subsection{Ptotal $=\mathrm{PH}_{2} \mathrm{O}=5 \mathrm{Kbar}$}

At pressure $5 \mathrm{kbar}$ the experiments have been performed at temperatures $\mathrm{T}=970 ; 980$ и $990^{\circ} \mathrm{C}$. In the run A69-3 $\left(\mathrm{T}=970^{\circ} \mathrm{C}\right)$ preheating was applied. In the main stage of the experiment homogeneous nucleation produces sparse centres of crystallization. Intergrowth of clinopyroxene and amphibole was observed (see Figure 4). Amphibole crystals gain the maximum sizes up to $150 \times 30 \mathrm{mkm}$. Clinopyroxene might experience faster homogeneous nucleation. It starts to grow first becoming the centre of the later amphibole overgrowth. High water content at $\mathrm{P}=5 \mathrm{Kbar}$ (about $8 \mathrm{wt} . \%$ ) reduces homogeneous nucleation rate resulting in the low volume crystal population density and larger crystal sizes.

The charge in the run at $\mathrm{T}=980^{\circ} \mathrm{C}$ (run An69-4) was also preheated (see Table 2). However, undercooling at the main stage of the experiment was too low to start homogeneous nucleation as in the run An68-5 at $\mathrm{P}=3 \mathrm{kbar}$. Homogeneous nucleation starts in the early moments of quenching (at the relatively low undercooling) and results in the formation of plenty of small lath -shape crystals uniformly distributed in the melt volume. Strike difference in the amphibole crystal morphology and sample texture was caused by such small run temperature difference as $10^{\circ} \mathrm{C}$.

There was no preheating in the run performed at $\mathrm{T}=990^{\circ} \mathrm{C}$ (An69-1). Only a small fraction of amphibole crystals has a shape with low elongation among numerous quenching amphibole laths. When plotted (see Figure 5) isometric crystal compositions stay for the growth at a small undercooling. In Figure 5 one can notice that compositions of amphiboles from the run An69-1 follow a linear trend along pressure indicator line with small scattering and that this line comprises the exact upper edge of the analyses set of the run An69-3 $\left(\mathrm{T}=970^{\circ} \mathrm{C}\right)$. The experiments at $\mathrm{T}=1030^{\circ} \mathrm{C}$ without superheating yields crystals of quenching origin judging by their composition with the volume crystal density lower than that in the run at $\mathrm{T}=990^{\circ} \mathrm{C}$. This observation demonstrates that $\mathrm{T}=1030^{\circ} \mathrm{C}$ is slightly above $\mathrm{T}_{1}$. Therefore, we tentatively determine amphibole liquidus temperature at $\mathrm{P}=5 \mathrm{Kbar}$ as $1005 \pm 5^{\circ} \mathrm{C}$. High water content in andesite melt at $\mathrm{P}=5 \mathrm{kbar}$ enhances diffusion and thus recrystallization rate. Therefore, the experiments at this pressure provide the most accurate in this study estimate of $\mathrm{Al}^{\mathrm{VI}}{ }_{\max }$ equal to 0.81 . 


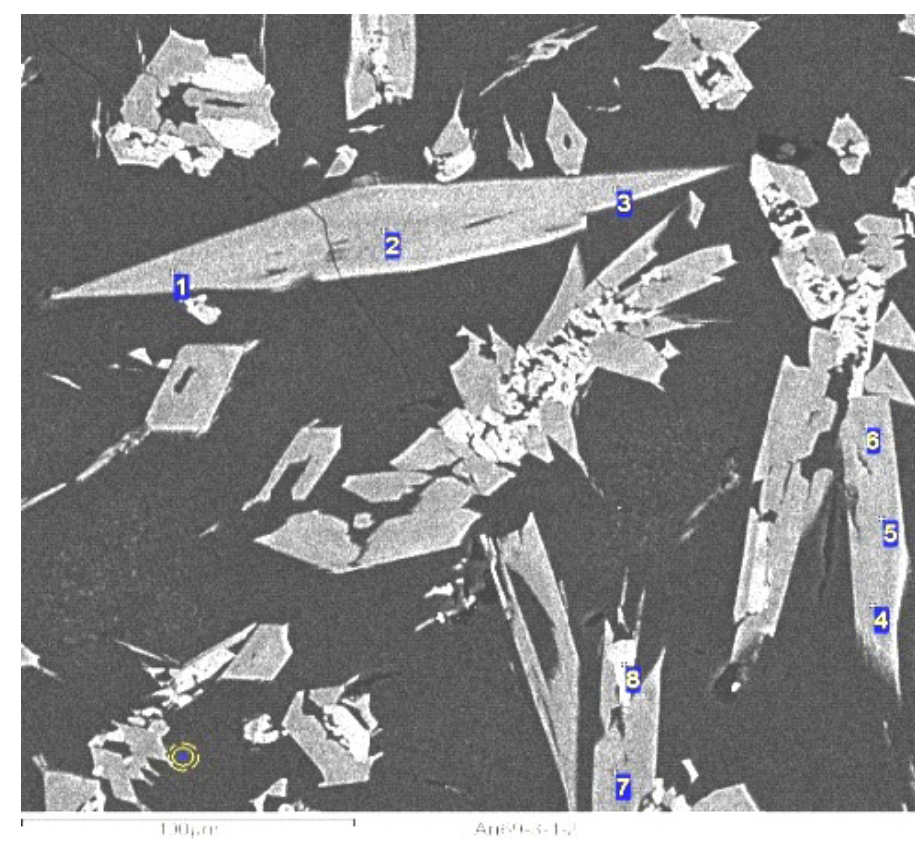

Figure 4. SEM image of the sample from the run An69-3 with parameters T=970oC, $\mathrm{P}=5 \mathrm{kbar}$, overheating. Dark crystals are amphiboles while bright ones are clinopyroxenes

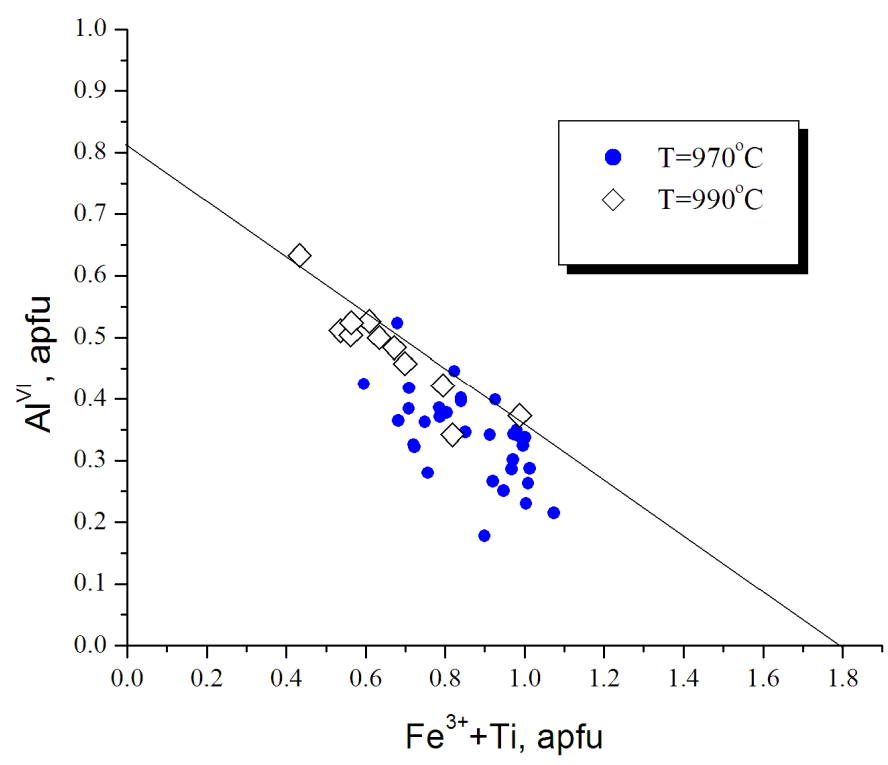

Figure 5. Compositions of amphiboles produced at $\mathrm{P}=5 \mathrm{kbar}$ with temperatures of the runs shown in the legend. Crystals produced at $\mathrm{T}=990^{\circ} \mathrm{C}$ close to the liquidus follow linear trend almost perfectly and used for calibration.

At $970^{\circ} \mathrm{C}$ amphiboles form large crystals along with clinopyroxenes causing appreciate melt fractionation reflected in the shift of amphibole compositions towards lower $\mathrm{Al}^{\mathrm{VI}}$ contents

The above data demonstrate growing maximum asymptotic aluminium content in the octahedral positions of amphibole structure $\mathrm{Al}^{\mathrm{VI}}$ max with pressure increase. It is most important that in our experiments we take the influence of undercoolings on the crystal composition into consideration. This effect is much larger than a thermodynamic shift of equilibrium compositions to lower equilibrium temperatures (e.g., decrease of $\mathrm{Mg} \#$ of minerals). Equilibration of nonequilibrium solids proceeds in experiments only through recrystallization since equilibration via the solid state diffusion in a crystal requires at least years (Pichavant et al. 2007). 
Recrystallization is effective only for the crystals of submicron size (Cabane et al., 2005). It is especially sluggish at low water content in the melt and small melt fraction. We relied in our study on the tuning of the run temperature to provide small undercoolings. At such strategy small temperature step experiments are performed around $\mathrm{T}_{1}$ instead of using regular T-grid with a larger step.

\section{Calibration of Dependence of $\mathrm{Al}^{\mathrm{VI}}{ }_{\text {max }}$ versus Pressure}

The values of $\mathrm{Al}^{\mathrm{VI}}$ max evaluated from our experimental data at $\mathrm{P}=2,3,5 \mathrm{Kbar}$ are well approximated as a linear function of pressure (see Figure 5a). Correlation Coefficient is 0.98 . To extend model pressure range and to look how this correlation works for different melt compositions we use the published experimental data on magmatic calcic amphiboles.

Using published compositions raises the problem of data selection since practically all experimental studies were aimed on the melting diagram investigation and amphibole compositions were obtained as a byproduct. As mentioned above, there are two main sources of errors: large undercooling and melt fractionation. Only near liquidus amphiboles grown at moderate undercoolings and low total degree of crystallization reflect pressure and initial melt composition. Another source of inaccuracy is to present the average of several compositions in publications. The average of the crystallochemical formulas is preferable and not equal to that of the composition average.

First we include all available high temperature amphibole data into the data set for calibration (Adam et al., 2007; Allen and Boettcher, 1983; Alonso-Perez et al., 2009; Berndt et al., 2005; Grove, et al., 2003; Foden and Green, 1992; Moore and Carmichael, 1998; Parat et al., 2008; Sato et al., 2005). A cloud of data points becomes more diffusive and obeys linear regression with a smaller correlation coefficient $r=0.89$ (see Figure 5b). Then we exclude sources demonstrating maximum deviations from the linear trend (Adam et al., 2007, Foden and Green, 1992, Sato et al., 2005, Moore and Carmichael, 1998). Other data points were retained as more reliable. On instance we select two points from 63 runs reported in (Berndt et al., 2005). All the experiments of these authors were performed at $\mathrm{P}=2$ kbar with a variable water contents and temperatures. We find that conditions $\mathrm{C}_{\mathrm{H} 2 \mathrm{O}} \approx 2 \mathrm{wt} . \%$ and $\mathrm{T}=950^{\circ} \mathrm{C}$ are rather close to amphibole liquidus. Improved data set defines a linear trend with the correlation coefficient $\mathrm{r}=0.99$ :

$$
\mathrm{Al}^{\mathrm{VI}}{ }_{\text {max }}=a+b P, a=0.4871 \pm 0.0219 ; \mathrm{b}=0.0623 \pm 0.0029
$$

We consider this regression as the $\mathrm{Al}^{\mathrm{VI}}$ in amphibole geo-barometer for petrologic applications. Below we propose a theoretical explanation for the observed correlation based on pressure induced structural transitions in the alumino-silicate melt.

\subsection{Aluminum Partitioning between Amphibole and Melt as a Basis for $A l^{V I}$ in Amphibole Barometer}

There were a lot of attempts to construct $\mathrm{Al}$ in amphibole geo-barometers based on a total content of aluminum (Hammarstrom \& Zen, 1986; Johnson \& Rutherford, 1989; Schmidt, 1992; Anderson \& Smith, 1995; Ridolfi et al., 2010). Our choice of octahedral aluminum instead of total as a pressure indicator can be supported with considerations related to the structure of the parental alumino-silicate melt.

In general, aluminum can take network-forming (tetrahedral) structural position in the melt along with silica and be cation modifier coordinated with 5 and 6 oxygens like $\mathrm{Mg}^{2+}, \mathrm{Ca}^{2+}$ and alkalies. As demonstrated by NMR concentration of five-coordinated aluminum is much higher than octahedrally coordinated one at a low pressure and becomes similar at high pressures of 4-6 GPa with totally about half aluminum in the high coordinated state (Kelsey et al., 2009). We assume that equilibrium fractionation of $\mathrm{Al}^{(\mathrm{V}+\mathrm{VI})}{ }_{\mathrm{L}}$ between melt and amphibole takes place.

Pressure has substantially higher influence on the octahedral aluminum content in amphibole since pressure range of amphibole growth in nature is from 2 to $15 \mathrm{kbar}$ while liquidus temperature for this mineral in adesites and basalts is in the range $930-1050{ }^{\circ} \mathrm{C}$. We expect the increase of $\mathrm{Al}^{\mathrm{V}+\mathrm{VI}}$ fraction in the melt on $200-300 \%$ (Kelsey et al., 2009) and 10\% (Stebbins et al., 2008) due to pressure and temperature variations, respectively.

Presence of aluminum in the cation-modifier form is unambiguously manifested by the easy nucleation of metastable corundum $\left(\mathrm{Al}_{2} \mathrm{O}_{3}\right)$ from the melt of anorthite composition preceding homogeneous nucleation of stable triclinic $\mathrm{CaAl}_{2} \mathrm{Si}_{2} \mathrm{O}_{8}$ (Abe et al., 1991). In accordance with Stebbins et al. (2008) $\mathrm{Al}^{\mathrm{V}}$ fraction at $\mathrm{T}=$ $1500^{\circ} \mathrm{C}$ (near anorthite liquidus) attains the level of ca $18 \%$. Similarly expanding of corundum field in the system An-Fo-Di at the expense of anorthite one at $\mathrm{P}=7 \mathrm{kbar}$ reflects a structural transition $\mathrm{AI}^{\mathrm{IV}}->\mathrm{Al}^{\mathrm{V}+\mathrm{VI}}$ in the melt (see e.g., Presnall et al., 1978).

Melt composition has also influence on the structural position of aluminum with the fraction of $\mathrm{Al}^{\mathrm{V}+\mathrm{VI}}$ markedly 
increasing in the melts, rich in high-strength cations (strength is defined as a ratio of charge to the square of cation diameter $\mathrm{f}=\mathrm{z} / \mathrm{D}^{2}$ ). Alkalies and calc-alkalies are ranged by strength as: $\mathrm{Mg}>\mathrm{Ca}>\mathrm{Na}>\mathrm{K}$ (Kelsey et al., 2009). Generally $\mathrm{Mg}$ content is inversely correlated with silica one, therefore, fraction of $\mathrm{Al}^{\mathrm{V}+\mathrm{VI}}$ is minimal in the most differentiated granitic melt (Malfait et al., 2011) and maximum in high magnesium andesitic and basaltic melts (Neuville et al., 2008). Dependence of the aluminum structural state on the melt composition precludes universal $\mathrm{Al}^{\mathrm{VI}}$ in amphibole geo-barometer. Fractionation effect was considered in our experimental data (see "dacitic bill" in Figure 3) above. In many publications experimental andesitic amphiboles due to this effect can be in equilibrium with dacitic and even rhyolitic melt. The inclusion of these minerals compositions into the data set for the calibration of geo-barometer for andesites and basalts (as probably in Ridolfi, 2010) would result in the weak and possibly erroneous correlation.

Aluminum in cation-modifier form has high activity not only in the least differentiated magmas, especially at high $\mathrm{P}$ but also in the fluid. Consideration of the amphibole composition in the $\left[\mathrm{Al}^{\mathrm{VI}}, \mathrm{Fe}^{3+}+\mathrm{Ti}\right]$ coordinates permits to distinguish between magmatic (grown from the melt) and metamorphic (formed from the fluid phase) amphiboles. Compositional trends for magmatic amphiboles intersects with abscissa at $\mathrm{Fe}^{3+}+\mathrm{Ti}\left(\mathrm{Cr}^{3+}\right)=1.8-1.9$ apfu. Plotting of the metamorphic amphibole compositions from (Imon et al., 2002) show that compositional trends are characterized by the higher $\mathrm{Al}^{\mathrm{VI}}=0.2-0.4$ apfu at the maximum observed values of the sum $\mathrm{Fe}^{3+}+\mathrm{Ti}=$ 2-2.2 apfu. This compositional feature may become a parameter to distinguish amphiboles formed from the melt in the complex systems from ones crystallized in the auto-metosomatic and metamorphic stages following magma solidification.

\subsection{Influence of Water and Alkalies}

According to the above model the content of $\mathrm{Al}^{\mathrm{VI}}$ in amphibole may increase at depolymerization of alumino-silicate melt at the reaction with water. It was well established that dissolution of the first weight percents of water proceeds with the formation of hydroxyls and mainly break of Si-O-Si and to less extent Si-O-Al bonds (Xue \& Kanazaki, 2006) with the expected detaching of some Al from network. Indeed with NMR method in the model andesitic Di62An38 system Xue and Kanazaki (2007) observed the increasing of Al ${ }^{\mathrm{V}}$ and $\mathrm{Al}^{\mathrm{VI}}$ fractions from 3.3 to $4.4 \%$ and from 0 to $1.8 \%$ respectively at the incorporation of $1.7 \mathrm{wt} . \%$ of water into anhydrous glass. However, NMR study of hydrous rhyolitic glasses reveals even reducing of $\mathrm{Al}^{\mathrm{V}} / \mathrm{Al}_{\text {total }}$ with water content increase (Wim et al., 2011). There is no conclusive model of Al speciation in the hydrous alumino-silcate melts that can be used to predict the effect of water on amphibole composition.

Alkalinity rise leads to the formation of aluminates (e.g., $\mathrm{Na}_{2} \mathrm{Al}_{2} \mathrm{O}_{4}$ (Simakin et al., 2010)) in the melt, where aluminum is network-forming component and thus, to the decreasing of $\mathrm{Al}^{\mathrm{V}+\mathrm{VI}}$ activity. Alkalinity influence may lead to pressure underestimation in the case of application of our geo-barometer to subalkaline and alkaline andesitic and basaltic hydrous magmas. The volume of the reliable experimental data on the amphibole crystallization from alkaline melts is too small to quantify this effect.

\subsection{Strategy of Geo-barometer Application}

Usually geo-sensors (geo-barometers, geo-thermometers, geo-oxygen barometers) are applied for each single analysis of the involved phase (one or several). The estimate by the set of values $\left(\mathrm{P}, \mathrm{T}\right.$ or $\mathrm{f}_{\mathrm{O} 2}$ ) is taken to correspond to the maximum of histogram or its mean value. In our case while avoiding amphibole microlyths one will not encounter the effect of undercooling on mineral composition since phenocrysts usually grow at the near liquidus temperature. However, melt composition can vary due to the fractionation and mixing effects thereby reducing $\mathrm{Al}^{\mathrm{V}+\mathrm{VI}}$ activity in a magma and $\mathrm{Al}^{\mathrm{VI}}$ in amphibole. Hence the desired pressure estimate can be obtained with the highest temperature amphiboles formed from the most primitive melt that can comprise only a fraction of all observed minerals. To solve this problem we plot analyses of amphiboles from nominally andesitic or basaltic magmas on the $\mathrm{Fe}^{3+}+\mathrm{Ti}-\mathrm{Al}^{\mathrm{VI}}$ diagram and define the upper edge (towards higher $\mathrm{Al}^{\mathrm{VI}}$ values) of the data points set. Pressure indicator line is drawn through this edge and predefined point $-\left[\mathrm{Fe}^{3+}+\mathrm{Ti}, \mathrm{Al}^{\mathrm{VI}}\right]=[1.8,0]$ to the intersection with the ordinate defining $\mathrm{Al}^{\mathrm{VI}}{ }_{\text {max. }}$. This parameter determines maximum pressure of growth for the amphibole crystal set in consideration. In some cases, e.g. for individual phenocryst (Simakin et al., 2009), data points on the master plot closely follow the pressure indicator line.

In the next section we consider the examples of the application of our $\mathrm{Al}^{\mathrm{VI}}$ in amphibole geo-barometer to the well studied geological objects: to andesites of Shiveluch volcano (Kamchatka) and to mafic xenoliths in alkaline basalts from Dish Hill (California) characterized by independent methods. 


\section{Geologic Applications}

\subsection{Shiveluch Volcano}

The Shiveluch volcano is located near the junction of Aleute and Kuril -Kamchatka subduction zones and marks a northern edge of the present day volcanic activity in Kamchatka. By total magma output it is the second and by andesites output it is the first among active volcanoes of Kuril -Kamchatka subduction zone (Gorbach \& Portnyagin, 2011). The andesites of the Young Shiveluch are classified as adakites for their high $\mathrm{MgO}$ and $\mathrm{Cr}$ content and high $\mathrm{Sr} / \mathrm{Y}$ ratio (Yogodzinski et al., 2001). They are also characterized by high water content and oxygen fugacity reaching $\mathrm{NNO}+2$. Twice in Holocene eruptions of high magnesium basalts with low water content, low $\mathrm{f}_{\mathrm{O} 2}$ and presumably high $\mathrm{CO}_{2}$ activity took place (7600 and $3600 \mathrm{BP}$ ) (Pevzner \& Babansky, 2010). For pressure estimate we use the analyses of amphiboles from the samples collected by A. Babansky (described in Simakin et al., 2009), by authors in 2007 and published in (Bryant et al., 2007; Ferlito, 2011). The most important are amphiboles substituting Opx from the ultramafic inclusions. We study undated pyroxenite inclusion hosted in andesite from the western slope of the volcano.

In this ultramafic inclusion orthopyroxene was partially replaced by amphibole and eventually overgrown by amphibole (rim) corona. Amphibole compositions are plotted in Figure 6a. We interpret the observed distribution from $\mathrm{Al}^{\mathrm{VI}}$ rich to $\mathrm{Al}^{\mathrm{VI}}$ poor varieties towards the inclusion center as manifestation of concentration decrease of aluminum transported by diffusion from andesitic melt and consumed in the substitution reaction. We specify pressure indicator line passing through the point $\left[\mathrm{Fe}^{3+}+\mathrm{Ti} \mathrm{Al}^{\mathrm{VI}}\right]=[1.8,0]$ and upper-right edge of xenolith points set. It intersects with the ordinate at $\mathrm{Al}^{\mathrm{VI}}$ max $=0.98$ with the corresponding equilibrium pressure $\mathrm{P}=7.9 \pm 0.8 \mathrm{kbar}$. Two-pyroxene geo-thermo-barometer (Putirka, 2008) gives us pressure estimate $\mathrm{P}=8.3 \pm 1.5 \mathrm{kbar}$ and temperature $\mathrm{T}=1013^{\circ} \mathrm{C}$. Ridolfi (2010) amphibole barometer yields $\mathrm{P}=3.4$ kbar.

Bryant et al. (2007) described inclusions of amphibolized pyroxenites from the andesites of the Young Shieluch eruption of 1964 as mantle xenoliths transported from sub-Moho depths to magma chamber. The analyses of amphiboles from this paper and pressure indicator line are plotted in Figure $6 \mathrm{~b}$. A small number of analyses permits only approximate pressure estimate of $\mathrm{P}=5.1 \pm 0.6 \mathrm{kbar}$. Two-pyroxene geo-barometer pressure estimate based on analyses published in (Bryant et al., 2007) is $5.6 \pm 1.1 \mathrm{kbar}\left(\right.$ at $\mathrm{T}=931^{\circ} \mathrm{C}$ ). Amphibole analyses from (Bryant et al., 2007) also tell us that intrinsic oxygen fugacity of pyroxenites was much lower $\left(\mathrm{Fe}^{3+}+\mathrm{Ti}=0.3-0.4\right)$ than that in the hosted andesitic magma $\left(\mathrm{Fe}^{3+}+\mathrm{Ti}=1.1-1.2\right)$ exactly as concluded by authors of cited publication (Bryant et al., 2007).

However, while using $\mathrm{Ca}$ in olivine geobarometer Bryant et al. (2007) predicts much higher pressure of 1-2 GPa for the same samples. It is known that olivine grown from the melt contains a lot of calcium. Olivine is purified and releases $\mathrm{CaO}$ at the solid state recrystallization and equilibration with pyroxene. $\mathrm{Ca}$ in olivine geo-barometer can be used only for such aggregates. While used for magmatic olivine this tool may give highly erroneous results (Medaris et al., 1999). Pressure 6-8 kbar corresponds to the crustal magma chamber rather than sub-Moho mantle depths anticipated by Bryant et al. (2007). We can conclude that the Shiveluch hydrous andesites mix with basic dry reduced magma on the middle to low crust level. Ridolfi (2009) model provides quite lower value of pressure $\mathrm{P}=3 \mathrm{kbar}$. Summarizing ultramafic inclusions data we can conclude that our novel amphibole geo-barometer predicts pressure values confirmed by independent method while Ridolfi (2010) amphibole barometer strongly underestimates it. 

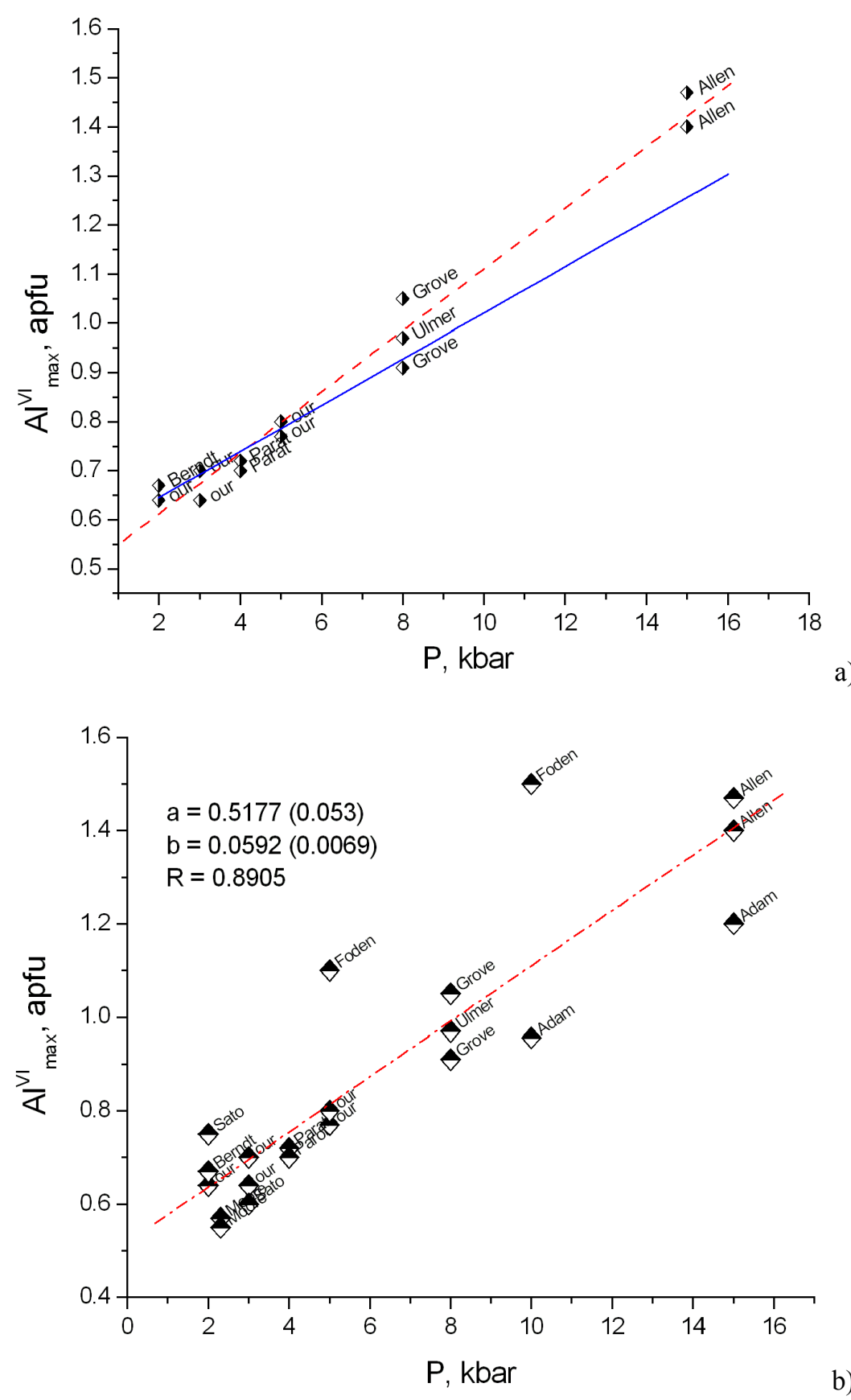

a)

Figure 6. Calibration of $\mathrm{Al}^{\mathrm{VI}}$ in amphibole geobarometer a) continuous line is linear regression of our experimental data obtained at $\mathrm{P}=2,3,5 \mathrm{kbar}$; dashed line represents linear regression of our data and selected published experimental results (points labeled with first names of the corresponding papers) b) regression of the more complete data set with inclusion of less precise points 

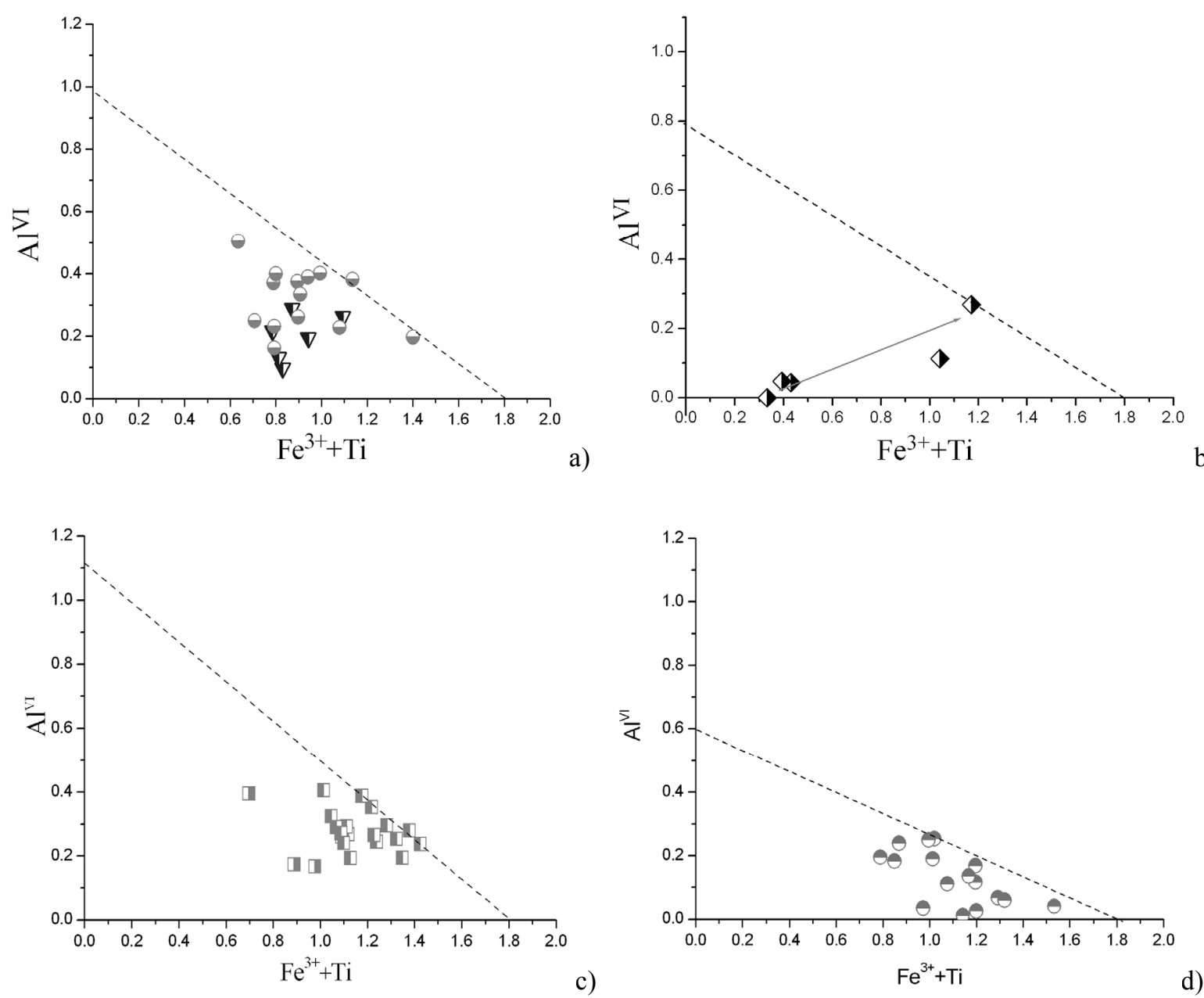

b)

Figure 7. Compositions of amphiboles from Shiveluch volcano, Kamchatka a) mafic inclusion from the N-W flank of volcano b) amphibolized mafic inclusion from (Bryant et al., 2007), arrow demonstrates trend from reduced and $\mathrm{Al}$ deficit conditions in the center of xenolith towards oxidized rims equilibrated with andesitic magma, pressure indicator lines in all plots are depicted with dotted line c) phenocrysts from Holocene extrusions from the N-W flank of volcano d) amphiboles from andesitic lava rested in the shallow chamber before eruption

Amphiboles from the Holocene extrusions located along the western edge of Old Shivelush caldera have surprisingly high pressure of formation in accordance with our estimates. In Figure $7 \mathrm{c}$ we plot our data for amphiboles from the Karan extrusion. Most analyses specify an unequivocal position of pressure indicator line with the expected abscissa intersection point $\left[\mathrm{Fe}^{3+}+\mathrm{Ti}, \mathrm{Al}^{\mathrm{VI}}\right]=[1.8,0]$. Pressure estimate for this sample is $\mathrm{P}=9.8 \pm 0.8 \mathrm{kbar}$ approximately corresponding to the Moho depth of $33 \mathrm{~km}$ in NE Kamchatka (Levin et al., 2002). We get essentially the same high pressure around $\mathrm{P}=10 \mathrm{kbar}$ at the consideration of the published analyses from Shiveluch extrusions found in (Gorbach \& Portnyagin, 2011; Ferlito, 2011).

For comparison in Figure 6d we place amphibole diagram for undated andesitic lava slab sampled on the western slope of Shiveluch. It yields $\mathrm{P}=2.2 \pm 0.4 \mathrm{kbar}$. This points set indicates shallow magma chamber under volcano with the depth of about $5 \mathrm{~km}$ (plus 2-3 km of edifice load). The points on this diagram almost uniformly fill the sector between pressure indicator line and abscissa reflecting a close system fractionation of magma towards silicic compositions before and probably during the eruption.

\subsection{Dish Hill Xenoliths}

In the above example our geo-barometer was used for high magnesium andesite i.e. exactly within the composition field used for calibration. Further we consider a case of lherzolite xenoliths from the Pliocene basanite cones, Dish Hill (California). These ultramafic xenoliths with numerous interstitial amphiboles and 
amphibole veins were described three decades ago (Wilshire et al., 1980) and since then have been intensively studied as a product of mantle metasomatose (Popp et al., 1995; Lamb \& Popp, 2009). Calcic amphibole analyses from (McGuire et al., 1991) are plotted in Figure 7. Two sets of points correspond to two different samples of spinel lherzolite (WR and DH abbreviation from (McGuire et al., 1991)). A rather small spreading around well defined pressure indicator lines can be observed. Pressure estimates are $\mathrm{P}=8.1 \pm 0.8 \mathrm{kbar}$ for WR and $\mathrm{P}=2 \pm 0.4 \mathrm{kbar}$ for $\mathrm{DH}$ samples, respectively. Two-pyroxene geo-thermo-barometer gives the following estimates: $\mathrm{P}=9 \pm 0.3 \mathrm{kbar}, \mathrm{T}=1060^{\circ} \mathrm{C}$ for $\mathrm{WR}$ and $\mathrm{P}=7.5 \pm 0.4 \mathrm{kbar}, \mathrm{T}=988^{\circ} \mathrm{C}$ for $\mathrm{DH}$ samples. Pressure evaluations with both methods for WR samples are practically the same within uncertainty limits. DH sample amphiboles were formed at the significantly lower pressure than two-pyroxene aggregate. We can interpret these facts as amphibolization of WR sample in-situ in Upper mantle and in the shallow magma chamber in the case of DH sample. Pressure estimates made by two-pyroxene and amphibole geo-barometers are significantly lower than 2 GPa proposed by Lamb and Popp (2009) based on the thermodynamic modeling. Coordinated pressure guess for Dish Hill xenoliths of 8-9 kbar corresponds well to the Moho depths of 27-29 km obtained with seismic methods (Miller, 2009). Like in the Shiveluch case we anticipate that mantle generated magma was ponded first at the upper mantle - crust density interface. At the further ascend toward the surface magma carried fragments of the deep magma chamber walls as lherzolite xenoliths.

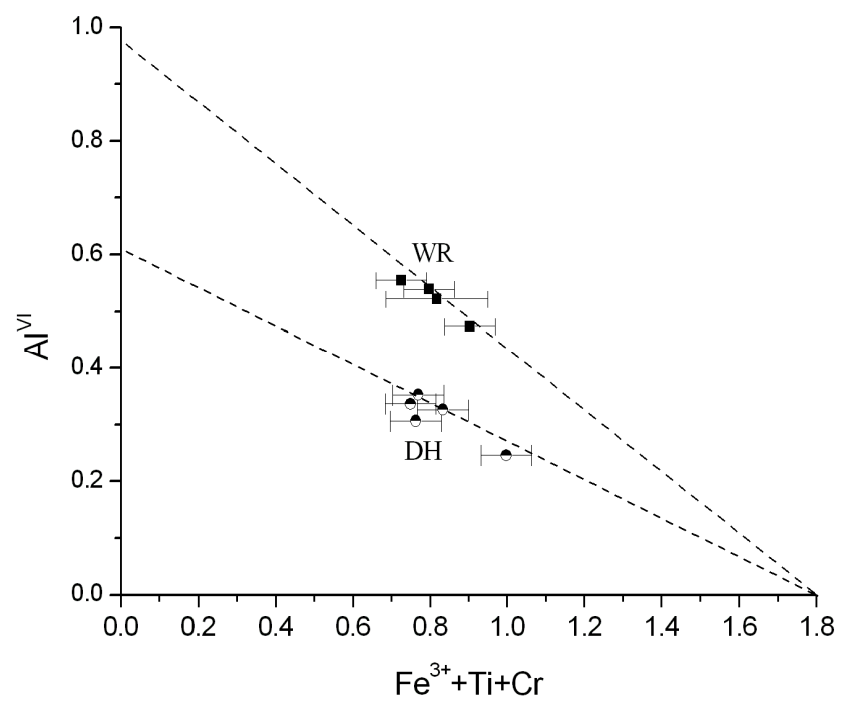

Figure 8. Amphiboles compositions of amphibolized mafic xenoliths from Dish Hill, California, source of data (McGuire et al., 1991). Upper pressure indicator line gives Moho depth pressure of xenoliths formation, lower data set corresponds to the pressure of the shallow magma chamber where DH sample was equilibrated before dyke intrusion

\section{Conclusions}

Amphibole is common phase crystallizing from hydrous magmas. This mineral composition can show a lot about physicochemical conditions of its formation. We perform experimental study of amphibole crystallization from high magnesium andesites (Shiveluch volcano, Kamchatka) at pressure of 2, 3 and 5 kbar. In our study we grow crystals at sufficiently low undercooling to minimize kinetic effect on the solid composition. The data obtained in this way permits calibration of $\mathrm{Al}^{\mathrm{VI}}$ in amphibole geobarometer. To extend the dependence of the extrapolated maximum $\mathrm{Al}^{\mathrm{VI}}$ content on higher pressures we additionally use the published experimental data that get linear regression $\mathrm{Al}^{\mathrm{VI}}{ }_{\text {max }}(\mathrm{P})$ with correlation coefficient 0.99 after some reasonable selection. Our model is based on the assumption of the equilibrium distribution of the Al presented in the cation-modifier form in the melt and octahedral $\mathrm{Al}$ in amphibole. It is important that at the constant bulk composition a structural transition of the tetrahedral aluminum (network-forming form) into higher coordinated $\mathrm{Al}^{\mathrm{V}}$ and $\mathrm{Al}^{\mathrm{VI}}$ forms (detached from the network) is essentially pressure induced. It was shown that novel geobarometer pressure estimates are consistent with two-pyroxene ones (Putirka, 2008) for several amphibolized ultramafic xenoliths. This ensures application of our $\mathrm{Al}^{\mathrm{VI}}$ in amphibole geobarometer for evaluation of hydrous magmas pressure of calc-alkaline andesitic to basaltic compositions. 


\section{Acknowledgements}

Authors express their gratitude to Alexey Nekrasov for performing precise microprobe analyses and Michail Ivanov for technical assistance in the experiments on IHPV. Olga Mozgovaya is cordially acknowledged for language corrections of the manuscript.

\section{References}

Abe, T., Sukamoto, K., \& Sunagawa, I. (1991). Nucleation, growth and stability of CaAl2Si2O8 polymorphs. Physics and Chemistry of Minerals, 17, 473-484.

Adam, J., Oberti, R., Cámara, F., \& Green, T. H. (2007). An electron microprobe, LAM-ICP-MS and single-crystal X-ray structure refinement study of the effects of pressure, melt-H2O concentration and on experimentally produced basaltic amphiboles. European Journal of Mineralogy, 19, 641-655. http://dx.doi.org/ 10.1127/0935-1221/2007/0019-1750

Allen, J. C., \& Boettcher, A. L. (1983). The stability of amphibole in andesite and basalt at high pressures. American Mineralogist, 68, 307-314. http://www.minsocam.org/ammin/AM68/AM68_307.pdf

Alonso-Perez, R., Muntener, O., \& Ulmer, P. (2009). Igneous garnet and amphibole fractionation in the roots of island arcs: experimental constraints on andesitic liquids. Contribution to Mineralogy and Petrology, 157, 541-558. http://dx.doi.org/10.1007/s00410-008-0351-8

Andersen, D. J., Lindsley, D. H., \& Davidson P. M. (1993). QUILF: a Pascal program to assess equilibria among $\mathrm{Fe}-\mathrm{Mg}-\mathrm{Mn}-\mathrm{Ti}$-oxides, pyroxenes, olivine, and quartz. Computers \& Geosciences, 19, 1333-1350. http://dx.doi.org/10.1016/0098-3004(93)90033-2

Anderson, J. L., \& Smith, D. R. (1995). The effects of temperature and fO2 on the Al-in-hornblende barometer. American Mineralogist, $80, \quad 549-559 . \quad$ Retrieved from http://www.minsocam.org/msa/ammin/toc/Articles_Free/1995/Anderson_p549-559_95.pdf

Berndt, J., Koepke, J., \& Holtz, F. (2005). An Experimental Investigation of the Influence of Water and Oxygen Fugacity on Differentiation of MORB at $200 \mathrm{MPa}$. Journal of Petrology, 46, 135-167. http://dx.doi.org/10.1093/petrology/egh066

Blundy, J., \& Holland, T. J. B. (1990). Calcic amphibole equilibria and a new amphibole-plagioclase geothermometer. Contribution to Mineralogy and Petrology, 104, 208-224. http://dx.doi.org/10.1007/BF00306444

Bryant, J. A., Yogodzinski, G. M., \& Churikova, T. G. (2007). Melt-mantle interactions beneath the Kamchatka arc: Evidence from ultramafic xenoliths from Shiveluch volcano. Geochemistry, Geophysics, Geosystems, 8, 1-24. http://dx.doi.org/10.1029/2006GC001443

Cabane, H., Laporte, D., \& Provost, A. (2005). An experimental study of Ostwald ripening of olivine and plagioclase in silicate melts: implications for the growth and size of crystals in magmas. Contribution to Mineralogy and Petrology, 150, 37-53. http://dx.doi.org/10.1007/s00410-005-0002-2

Deer, W. A., Howie, R. A., \& Zussman, J. (1997) Rock-forming minerals, Chain Silicates, 2B, (2 ${ }^{\text {nd }}$ ed.). The Geological Society, London.

Ferlito, C. (2011). Bimodal geochemical evolution at Sheveluch stratovolcano, Kamchatka, Russia: Consequence of a complex subduction at the junction of the Kuril Kamchatka and Aleutian island arcs. Earth-Science Reviews, 105, 49-69. http://dx.doi.org/10.1016/j.earscirev.2010.12.003

Foden, J. D., \& Green, D. H. (1992). Possible role of amphibole in the origin of andesite: some experimental and natural evidence. Contribution to Mineralogy and Petrology, 109, 479-493. http://dx.doi.org/10.1007/BF00306551

Gorbach, N. V., \& Portnyagin, M. V. (2011). Geology and Petrology of the Lava Complex of Young Shiveluch Volcano, Kamchatka. Petrology, 19, 134-166. http://dx.doi.org/10.1134/S0869591111020068

Grove, T. L. Elkins-Tanton, L. T., Parman, S. W., Chatterjee, N., Muntener, O., \& Gaetani, G. A. (2003). Fractional crystallization and mantle-melting controls on calc-alkaline differentiation trends. Contribution to Mineralogy and Petrology, 145, 515-533. http://dx.doi.org/10.1007/s00410-003-0448-z

Gualda, G. A. R., \& Vlach, S. R. F. (2005). Stoichiometry-based estimates of ferric iron in calcic, sodic-calcic and sodic amphiboles: A comparison of various methods. Anais da Academia Brasileira de Ciências, 77, 521-534. http://dx.doi.org/10.1590/S0001-37652005000300012 
Hammarstrom, J. M., \& Zen, E. A. (1986). Aluminum in hornblende: an empirical igneous geobarometer. American Mineralogist, 71, 1297-1313. http://www.minsocam.org/ammin/AM71/AM71_1297.pdf

Imon, R., Okudaira, T., \& Fujimoto, A. (2002). Dissolution and precipitation processes in deformed amphibolites: an example from the ductile shear zone of the Ryoke metamorphic belt, SW Japan. Journalof Metamorphic Geology, 20, 297-308. http://dx.doi.org/10.1046/j.1525-1314.2002.00367.x

Johnson, M. E., \& Rutherford, M. J. (1989). Experimental calibration of the aluminum-in-hornblende geobarometer with application to Long Valley caldera (California) volcanic rocks. Geology, 17, 837-841. http://dx.doi.org/10.1130/0091-7613(1989)017<0837:ECOTAI>2.3.CO;2

Kelsey, K. E., Stebbins, J. F., Singer, D. M., Brown, G. E., Jr., Mosenfelder, J. L., \& Asimow, P. D. (2009). Cation field strength effects on high pressure aluminosilicate glass structure: Multinuclear NMR and La XAFS results. Geochimica et Cosmochimica Acta, 73(13), 3914-3933. http://dx.doi.org/10.1016/j.gca.2009.03.040

Lamb, W. M., \& Popp, R. K. (2009). Amphibole equilibria in mantle rocks: Determining values of mantle aH2O and implications for mantle $\mathrm{H} 2 \mathrm{O}$ contents. American Mineralogist, 94, 41-52. http://dx.doi.org/10.2138/am.2009.2950

Leake, B. E., Woolley, A. R., Arps, C. E. S., Birch, W. D., Gilbert, M. C., Grice, J. D., .. Youzhi, G. (1997). Nomenclature of amphiboles: Report of the Subcommittee on Amphiboles of the International mineralogical Association, Commission on New Minerals and Mineral Names. American Mineralogist, 82, 1019-1037. http://www.minsocam.org/msa/ima/ima98(11).pdf

Levin, V., Park, J., Brandon, M., Lees, J., Peyton, V., Gordeev, E., \& Ozerov, A. (2002). Crust and upper mantle of Kamchatka from teleseismic receiver functions. Tectonophysics, 358, 233-265. http://dx.doi.org/10.1016/S0040-1951(02)00426-2

Malfait, W., Xue, X., Verel, R., Ardia, P., \& Sanchez-Valle, C. (2011). The speciation of hydrous aluminosilicate glasses and melts: a view from NMR, infrared and Raman spectroscopy. Geophysical Research Abstracts, 13, EGU2011-1404 http://meetingorganizer.copernicus.org/EGU2011/EGU2011-1404.pdf

Manley, C., \& Bacon, C. R. (2000). Rhyolite thermobarometry and the shallowing of the magma reservoirs, Coso volcanic field, California. Journal of Petrology, 41, 149-174. http://dx.doi.org/10.1093/petrology/41.1.149

McGuire, A. V., Dyar, M. D., \& Nielson J. E. (1991). Metasomatic oxidation of upper mantle peridotite. Contribution to Mineralogy and Petrology, 109, 252-264. http://dx.doi.org/ 10.1007/BF00306483

Medaris, G. L., Wang, H. F., Fournelle, J. H., Zimmer, J. H., \& Jelínek, E. (1999). A cautionary tale of spinel peridotite thermobarometry: an example from xenoliths of Kozakov Volcano, Czech Republic. Geolines, 9 , 92-96. http://geolines.gli.cas.cz/fileadmin/volumes/volume09/G9-092.pdf

Miller, M. S. (2009). Receiver Function Images of the Western U.S. Lithosphere Using Transportable Array Data. Retrieved from http://www.earthscope.org/es_doc/onsite/Su09_WUSRecFunc.pdf

Moore, G., \& Carmichael, I. S. E. (1998). The hydrous phase equilibria (to $3 \mathrm{kbar}$ ) of an andesite and basaltic andesite from western Mexico: constraints on water content and conditions of phenocryst growth. Contribution to Mineralogy and Petrology, 130, 304-319. http://dx.doi.org/ 10.1007/s004100050367

Moretti, R., \& Baker, D. R. (2008). Modeling the interplay of fO2 and fS2 along the FeS-silicate melt equilibrium. Chemical Geology, 256, 286-298. http://dx.doi.org/10.1016/j.chemgeo.2008.06.055

Neuville, D. R., Cormier, L., Montouillout, V., Florian, P., Millot, F., Rifflet J. C., \& Massiot, D. (2008). Structure of $\mathrm{Mg}$ - and $\mathrm{Mg} / \mathrm{Ca}$ aluminosilicate glasses: 27Al NMR and Raman spectroscopy investigations. American Mineralogist, 93, 1721-1731. http://dx.doi.org/10.2138/am.2008.2867

Parat, F., Holtz, F., \& Feig, S. (2008). Pre-eruptive Conditions of the Huerto Andesite (Fish Canyon System, SanJuanVolcanic Field, Colorado): Influence of Volatiles (C-O-H-S) on Phase Equilibria and Mineral Composition. Journal of Petrology, 49, 911-935. http://dx.doi.org/10.1093/petrology/egn011

Pevzner, M. M., \& Babansky, A. D. (2010). Age of Young Shiveluch volcano and evolution of its magmas composition. Magmatism and metamorphism in the Earth history. In: Magmatism and Metamorphism in the Earth History. Proceedings of XI All-Russian Petrographic conference, Ekaterenburg, II, 115-116

Pichavant, M., Costa, F., Burgisser, A., Scaillet, B., Martel, C., \& Poussineau, S. (2007). Equilibration Scales in Silicic to Intermediate Magmas: Implications for Experimental Studies. Journal of Petrology, 48, 
1955-1972. http://dx.doi.org/10.1093/petrology/egm045

Popp R. K., Virgo, D., Yoder, H. S., J. R., Hoering T. C., \& Phillips, M. W. (1995). An experimental study of phase equilibria and Fe oxy-component in kaersutitic amphibole: Implications for the $\mathrm{fH} 2$ and $\mathrm{aH} 20$ in the upper mantle. American Mineralogist, 80, 534-548. Retrieved from http://www.minsocam.org/msa/ammin/toc/Articles_Free/1995/Popp_p534-548_95.pdf

Presnall, D. C., Dixon, S. A., Dixon, J. R., O'Donnell, T. H., Brenner, N. T., \& Dycus, D. W. (1978). Liquidus phase relations on the join diopside-forsterite-anorthite from $1 \mathrm{~atm}$ to $20 \mathrm{kbar}$ : Their bearing on the generation and crystallization of basaltic magma. Contributions to Mineralogy and Petrology, 66, 203-220. http://dx.doi.org/10.1007/BF00372159

Putirka, K. (2008). Thermometers and Barometers for Volcanic Systems. In: K. Putirka, F. Tepley, (Eds.), Minerals, Inclusions and Volcanic Processes. Reviews in Mineralogy and Geochemistry, 69, 61-120. http://dx.doi.org/10.2138/rmg.2008.69.3

Ridolfi, F., Renzulli, A., \& Puerini, M. (2010). Stability and chemical equilibrium of amphibole in calc-alkaline magmas: an overview, new thermobarometric formulations and application to subduction-related volcanoes. Contributions to Mineralogy and Petrology, 160, 45-66. http://dx.doi.org/10.1007/s00410-009-0465-7

Sato, H., Holtz, F., Behrens, H., Botcharnikov, R., \& Nakada, S. (2005). Experimental Petrology of the 1991-1995 Unzen Dacite, Japan. Part II: Cl/OH Partitioning between Hornblende and Melt and its Implications for the Origin of Oscillatory Zoning of Hornblende Phenocrysts. Journal of Petrology, 46, 339-354. http://dx.doi.org/10.1093/petrology/egh078

Schmidt, M. W. (1992). Amphibole composition in tonalite as a function of pressure: An experimental calibration of the Al-in-hornblende barometer. Contribution to Mineralogy and Petrology, 110, 304-310. http://dx.doi.org/10.1007/BF00310745

Simakin, A. G., \& Salova, T. P. (2004). Plagioclase Crystallization from a Hawaiitic Melt in Experiments and in a Volcanic Conduit. Petrology, 12(1), 82-92.

Simakin, A. G., Salova, T. P., \& Babansky, A. D. (2009). Amphibole Crystallization from a Water-Saturated Andesite Melt: Experimental Data at $\mathrm{P}=2$ kbar. Petrology, 17(6), 1-16. http://dx.doi.org/10.1134/S086959110906006X

Simakin, A. G., Salova, T. P., \& Eremyashev, V. E. (2010). Mechanism of water solubility in silicate melts of the $\begin{array}{llll}\text { albite-nepheline system. Mineralogy and Petrology, 99, 279-285. } & \end{array}$ http://dx.doi.org/10.1007/s00710-009-0107-9

Stebbins, J. F., Dubinsky, E. V., Kanehashi, K., \& Kelsey, K. E. (2008). Temperature effects on non-bridging oxygen and aluminum coordination number in calcium aluminosilicate glasses and melts. Geochimica et Cosmochimica Acta, 72, 910-925. http://dx.doi.org/10.1016/j.gca.2007.11.018

Wilshire, H. G., Pike, J. E. N., Meyer, C. E., \& Schwarzman, E.C. (1980). Amphibole-rich veins in lherzolite xenoliths, Dish Hill and Deadman Lake, California. American Journal of Science, 280, 576-593. http://earth.geology.yale.edu/ ajs/1980/ajs_280A_1.pdf/576.pdf

Xue, X., \& Kanzaki, M. (2006). Depolymerization effect of water in aluminosilicate glasses: Direct evidence from 1H-27Al heteronuclear correlation NMR. American Mineralogist, 91, 1922-1926. http://dx.doi.org/10.2138/am.2006.2365

Xue, X., \& Kanzaki, M. (2007). Al coordination and water speciation in hydrous aluminosilicate glasses: Direct evidence from high-resolution heteronuclear 1H-27Al correlation NMR. Solid State Nuclear Magnetic Resonance, 31, 10-27. http:// dx.doi.org/10.1016/j.ssnmr.2006.11.001

Yogodzinski, G. M., Lees, J. M., Churikova, T. G., Dorendorf, F., Woerner, G., \& Volynets, O. N. (2001). Geochemical evidence for the melting of subducting oceanic lithosphere at plate edges. Nature, 409, 500-504. http://dx.doi.org/10.1038/35054039 